\title{
Role of Micronutrients in Improving Yield and Quality of Seeds in Fenugreek Plants ( Trigonella foenim graecum L.)
}

\author{
M. S. Boghdady" \\ Agricultural Botany Department, Faculty of Agriculture, Zagazig University, Zagazig, \\ Egypt.
}

$\mathbf{T}$ HIS STUDY was conducted during the two winter seasons of 2015/2016 and 2016/2017 at Met Rabia Village, (Private Farm) Bilbas, Sharkia Governorate, Egypt, to study the impact of foliar spraying with micronutrients on growth, chemical composition, yield and anatomy of stem and leaves of fenugreek cv. Giza 3 .Micronutrients were sprayed at concentrations of $0,0.25,0.50,0.75$ and $1.00 \mathrm{ml} / \mathrm{L}$. The most significant promotion was recorded when fenugreek plants were sprayed with $0.75 \mathrm{ml} / \mathrm{L}$ micronutrients. This treatment gave beneficial changes in both morphological and crop characteristics. Foliar spraying with micronutrients at $0.75 \mathrm{ml} / \mathrm{L}$ increased the main stem diameter, cortex thickness, vascular cylinder, number of vascular bundles, except that of thickness of epidermis, fibrous tissue and pith diameter. Foliar application with micronutrients at $0.75 \mathrm{ml} / \mathrm{L}$ increased thickness of both lamina leaflet blades and midvein of fenugreek plants cv. Giza 3. It is clear that the increase in thickness of lamina is due to the increase in thickness of spongy and palisade tissues. The main vascular bundle of the midvein bundle increased in size. Number of xylem vessels /midvein bundle increased.

Keywords: Fenugreek, Micronutrients , Plant growth, Yield, Anatomy, Seed quality.

\section{Introduction}

Fenugreek (Trigonella foenim graecum L.) is an annual plant in the family Fabaceae.Fenugreek is used as a spicily and medicine. It is known to have hypoglycemic and hypocholesterolemic effects. Fenugreek is used as a source in the preparation of raw materials in the pharmaceutical industry, especially steroidal hormones (Petit et al., 1995) Seeds and leaves of fenugreek are used in many nations for other goals such as medicinal utility (anti diabetic, level of cholesterol and diminution blood sugar, anti-microbial, anti-cancerous), food Industry (powder of seed with flour for making flat bread in Egypt, stew with rice in Iran, bitter run and syrup in Germany, flavor cheese in Switzerland, seedling eaten as a vegetables) and roasted seeds is used as a coffee in Africa (Srinivasan, 2006). Seeds of mucilaginous are considered to have several medicinal virtues as a demulcent, emollient, tonic , diuretic, carminative, restorative, aphoristic and vermifugal and were used to cure mouth ulcers , stomach irriation and chapped lips (Duke, 1986 ).

Iron has an essential role as an involved enzyme components in electrons transfer and cytochromes. It is reflective oxidizes from $\mathrm{Fe}^{+2}$ to $\mathrm{Fe}^{+3}$ during electron transfer (Bienfait \& Van der Mark, 1993). Iron is necessary for the synthesis of chlorophyll, it is found in ferredoxin and flavoprotien. Also, it plays substantial role in respiration (Verma, 2007)

Boron plays main roles in elongation of cell, synthesis of nucleic acid, hormone responses and function of membrane (Shelp, 1993 ).

Many enzymes require manganese ions for their activity in plant cells. e.g., dehydrogenases and decarpoxylases involved in the Krebs cycle are activated by manganese. The best role of manganese is the transfer of electrons reaction in which oxygen is produced from water. It plays role in the synthesis of chlorophyll and the electrons transfer from $\mathrm{H}_{2} \mathrm{O}$ to photo- oxidized chlorophyll in photosynthesis (Marchner, 1995 ).

Zinc function as an enzyme activator in some reactions, e.g., carbonic anhydrase, hexose kinase and alcohol dehydrogenase. Zinc is important for the biosynthesis of the indole-3-acetic acid. It is believed to be concerned with protein metabolism and photosynthesis (Verma, 2007 ) .

\#Corresponding author email: hdeeby03@gmail.com

DOI:10.21608/agro.2017.1302.1068,

C2017 National Information and Documentation Centre (NIDOC) 
Sulphur is absorbed from the soil as sulphate ion. It is used in this formation bearing amino acids.e.g., cystine, cysteine and methionine. It is essential for the synthesis of vitamins (thiamine), coenzyme A., constituent of ferredoxin and essential role in determining protein synthesis and activation of enzymes (Verma , 2007 ) .

Copper is absorbed in the form $\mathrm{Cu}^{+2}$. It is contributory with enzymes in oxidation reactions, an example of such enzyme is plastocyanin, which is associated in photosynthesis by transfer of electron in light reactions (Haehnel, 1984). In fact, the amount of seeds in plants is related to the amount absorbed by these elements (Loomis \& Conner, 1992 ).
Through this work, the auther clarify the role of micronutrients in improving yield, seed quality and anatomical structure of fenugreek cv. Giza 3.

\section{Materials and Methods}

This work was carried out during the two successive winter seasons of 2015/2016 and 2016/ 2017 at Met Rabia village, (Private Farm) Bilbas, Sharkia Governorate, Egypt, to study the effect of foliar application with micronutrients on plant growth of fenugreek, yield and its components and seed quality as well as anatomy of stem and leaves of fenugreek cv. Giza 3 grown in clay loam soil.The physical and chemical analysis of the experimental soil are presented in Table 1.

TABLE 1. Physical and chemical properties of the experimental soil (season 2015/ 2016).

\begin{tabular}{|c|c|c|c|c|c|}
\hline \multicolumn{6}{|c|}{ Properties } \\
\hline & Mechanical & \multicolumn{4}{|c|}{ Chemical (mg/100 g soil) } \\
\hline Sand \% & 27.92 & $\mathrm{pH}$ & 7.21 & $\mathrm{Ca}++$ & 0.06 \\
\hline Silt $\%$ & 33.75 & $\mathrm{EC} \mathrm{mmohs/cm}$ & 1.53 & $\begin{array}{c}\mathrm{Mg}++ \\
\mathrm{Na}+\end{array}$ & $\begin{array}{l}0.04 \\
0.31\end{array}$ \\
\hline Clay\% & 38.33 & Total N\% & 0.04 & $\mathrm{CO}^{-}$ & - \\
\hline Soil texture & Clay loam & Total P\% & 0.05 & $\begin{array}{c}\mathrm{HCO} 3 \\
\mathrm{Cl}^{-}\end{array}$ & $\begin{array}{l}0.15 \\
0.14\end{array}$ \\
\hline F.C $\% *$ & 31.35 & Total K\% & 0.028 & $\mathrm{SO}^{-}$ & 0.12 \\
\hline
\end{tabular}

*Field capacity

Micronutrients was sprayed at concentrations of $0,0.25,0.50,0.75$ and $1.00 \mathrm{ml} / \mathrm{L}$. The control plants were sprayed with tap water. These treatments were arranged in a randomized complete block design with three replicates.

The fenugreek cv. Giza 3 were sown on $15^{\text {th }}$ November in both growing seasons, after inoculation with root nodules bacteria (Rhizobium leguminosarum). The area of experimental plot was four rows with $4 \mathrm{~m}$ length , $50 \mathrm{~cm}$ apart and hill were spaced at $30 \mathrm{~cm}$ distance, five seeds were sown in each hill, then thinned to one plant/ hill. One row was left between each two experimental units as a gourd row to avoid the overlapping of spraying solution of micronutrients. One row was used for samples to measure vegetative growth and the other three rows were used for yield determination.

The source of fenugreek cv. Giza 3 seeds was Legume Research Department, Field Crop Institue, Agric. Res. Center,Giza, Egypt. The source of root nodule bacteria was the General
Organization for Agriculture Equalization Found (G.O.A.E.F.), Ministry of Agriculture, Egypt. Chelated micronutrients obtained from Union for Agricultural Development Company, ALMokatom, Giza, Egypt, and contain of $\mathrm{Fe}(2.5 \%)$, $\mathrm{Zn}(2 \%), \mathrm{Mn}(1.5 \%), \mathrm{B}(0.5 \%), \mathrm{Cu}(2 \%)$ and $\mathrm{S}(4.5 \%)$. Fenugreek plants were sprayed with solution of micronutrients two times at 30 and 60 days after sowing. Each plot received 1.5 liters in the first application and 2.25 liters in the second one. The normal practices for growing fenugreek were carried out through two growing seasons. Tween 20 at $0.5 \%$ was used as wetting agent.

\section{The data recorded}

A random sample of twelve plants was randomly taken from each experimental unit at 90 days after sowing in both seasons and the following data were recorded:

I-Morphological characters

1-Stem length $(\mathrm{cm})$.

2- Plant height $(\mathrm{cm})$.

3- Number of leaves / plant. 
4-. Number of branches/ plant

5 -Fresh weight of shoot / plant.

6-. Dray weight of shoot / plant

Dry weight: The different plant parts; i.e., branches and leaves were oven dried at $70^{\circ} \mathrm{C}$ till constant weight, then dry weight of branches and leaves $(\mathrm{g})$ were recorded according to A.O.A.C. (1980).

\section{II-Yield and its components}

A random sample of twelve plants was taken from each treatment at 150 days after sowing and the following data were recorded:

1. Average number of pods/ plant.

2. Average number of seeds/ plant

3 -Yield of seeds / plant ( $\mathrm{g})$.

4- Weight of 100 seeds ( $g$ )

\section{Seed chemical constituents}

At harvest time of the second season, samples of mature seeds were prepared to determine nitrogen percentage, total crude protein percentage, seed oil percentage and total phenolic compounds as follows:

\section{Nitrogen percentage}

Nitrogen was determined in the seeds on the basis of dry weight according to Bremner \& Mulvaney (1982).

\section{Total crude protein percentage}

The determined nitrogen in the seeds was used for calculated total crude protein by multiplying $\mathrm{N}$ value by 6.25 (A.O.A.C. , 1980).

\section{Oil percentage}

Seed oil content was determined by using soxhelt extraction apparatus using petroleum ether as a solvent and then the seed oil percentage was calculated on dry weight basis according to A.O.A.C. (1990).

\section{Determination of total phenolic compounds}

The concentration of total phenols in all extracts were measured by a UV spectrophotometer (Jenway-UV-VIS Spectrophotometer), based on a colorimetric oxidation/reduction reaction, as described by Škerget et al. (2005). The used oxidizing reagent was Folin-Ciocalteu reagent (A.O.A.C., 1990). To $0.5 \mathrm{~mL}$ of diluted extract $(10 \mathrm{mg}$ in $10 \mathrm{~mL}$ solvent) $2.5 \mathrm{~mL}$ of Folin-Ciocalteu reagent (diluted 10 times with distilled water) and $2 \mathrm{~mL}$ of $\mathrm{Na}_{2} \mathrm{CO}_{3}(75 \mathrm{~g} / 1 \mathrm{~L})$ were added. The sample was incubated for $5 \mathrm{~min}$ at $50^{\circ} \mathrm{C}$ and then cooled For a control sample, $0.5 \mathrm{~mL}$ of distilled water was used. The absorbance was measured at $763 \mathrm{~nm}$. Total phenolic content expressed as gallic acid equivalent (GAE) was calculated using the following linear equation based on the calibration curve:

$$
\mathrm{y}=0.015 \mathrm{x} \quad \mathrm{r}^{2}=0.9966
$$

where $\mathrm{y}$ is the absorbance and $\mathrm{x}$ is the concentration (mg GAE g $\mathrm{g}^{-1}$ extract).

$\mathrm{r}^{2}=$ Correlation Coefficient

\section{Anatomical structure}

It was intended to carry out a comparative micorscopical examination on plant material which showed the most prominent response of plant growth to investigated treatments. Specimens of fenugreek cv. Giza 3 were taken from the fifth internode which resembled the median internode of the main stem as well as from the terminal leaflet of the corresponding leaf. Plants used for examination were taken throughout the second season at the age of 80 days. Specimens were killed and fixed for at least $48 \mathrm{~h}$. in FAA ( $10 \mathrm{ml}$ formalin, $5 \mathrm{ml}$ glacial acetic acid and $85 \mathrm{ml}$ ethyl alcohol $70 \%$ ). The selected materials washed in $50 \%$ ethyl alcohol, dehydrated in normal butyle alcohol series, embedded in paraffin wax of $56^{\circ} \mathrm{C}$ melting point, sectioned to a thickness of 20 microns, double stained with safranin and fast green, cleared in xylene and mounted in Canada balsam (Nassar \& El-Sahhar, 1998). Sections were examined to detected histological manifestations of the chosen treatments and photomicrography made.

\section{Statistical analysis}

Data on morphological and yield characters as well as on seed quality were subjected to conventional methods of analysis of variance according to Snedecor \& Cochran (1982). The least significant difference (L.S.D.) for each character was calculated at 0.05 level of probability.

\section{Result and Disscussion}

Morphological characters

The effect of micronutrients on morphological characters of fenugreek plants throughout 2015/ 2016 and $2016 / 2017$ seasons are presented in Table 2 . 
TABLE 2. Impact of micronutrients at different concentrations on vegetative growth parameters of fenugreek plants.

\begin{tabular}{|c|c|c|c|c|c|c|c|c|c|c|c|c|}
\hline \multirow[t]{2}{*}{ Treatments } & \multicolumn{2}{|c|}{$\begin{array}{l}\text { Length of the } \\
\text { main stem }(\mathrm{cm})\end{array}$} & \multicolumn{2}{|c|}{$\begin{array}{c}\text { Plant height } \\
\text { (cm) }\end{array}$} & \multicolumn{2}{|c|}{$\begin{array}{c}\text { No. of leaves/ } \\
\text { plant }\end{array}$} & \multicolumn{2}{|c|}{$\begin{array}{c}\text { No. of branches/ } \\
\text { plant }\end{array}$} & \multicolumn{2}{|c|}{$\begin{array}{l}\text { Fresh weight of } \\
\text { shoot (g) / plant }\end{array}$} & \multicolumn{2}{|c|}{$\begin{array}{l}\text { Dry weight of } \\
\text { shoot (g) / plant }\end{array}$} \\
\hline & $\begin{array}{c}1^{\text {st }} \\
\text { season }\end{array}$ & $\begin{array}{c}2^{\text {nd }} \\
\text { season }\end{array}$ & $\begin{array}{c}1^{\text {st }} \\
\text { season }\end{array}$ & $\begin{array}{c}2^{\text {nd }} \\
\text { season }\end{array}$ & $\begin{array}{c}1^{\text {st }} \\
\text { season }\end{array}$ & $\begin{array}{c}2^{\text {nd }} \\
\text { season }\end{array}$ & $\begin{array}{c}1^{\text {st }} \\
\text { season }\end{array}$ & $\begin{array}{c}2^{\text {nd }} \\
\text { season }\end{array}$ & $\begin{array}{c}1^{\text {st }} \\
\text { season }\end{array}$ & $\begin{array}{c}2^{\text {nd }} \\
\text { season }\end{array}$ & $\begin{array}{c}1^{\text {st }} \\
\text { season }\end{array}$ & $\begin{array}{c}2^{\text {nd }} \\
\text { season }\end{array}$ \\
\hline Control & 30 & 32.6 & 32.6 & 36.6 & 23.3 & 21.6 & 3.6 & 3.3 & 35.5 & 34.1 & 10.5 & 10.1 \\
\hline $0.25 \mathrm{ml} / \mathrm{L}$ & 32.6 & 34 & 35.6 & 37.5 & 28 & 26.3 & 3.9 & 3.6 & 41.1 & 39.6 & 12.7 & 11.9 \\
\hline $0.50 \mathrm{ml} / \mathrm{L}$ & 37 & 38.1 & 40.2 & 43 & 35.3 & 31.6 & 4.5 & 4.1 & 46.3 & 45.2 & 13.9 & 13.5 \\
\hline $0.75 \mathrm{ml} / \mathrm{L}$ & 52.3 & 49.6 & 55.3 & 53.7 & 41.3 & 36.6 & 5.5 & 5.2 & 54.1 & 55.6 & 15.5 & 16.1 \\
\hline $1.00 \mathrm{ml} / \mathrm{L}$ & 48.3 & 47 & 54.3 & 50 & 39.3 & 35 & 5.3 & 4.6 & 49.5 & 48.7 & 14.8 & 14.2 \\
\hline L.S.D. 0.05 & 5.08 & 4.52 & 7.20 & 6.23 & 4.29 & 3.40 & 0.83 & 0.65 & 4.75 & 4.53 & 1.57 & 1.72 \\
\hline
\end{tabular}

\section{Length of the main stem}

The obtained results in Table 2 indicated that all concentrations of micronutrients used except $0.25 \mathrm{ml} / \mathrm{L}$ promoted significantly in stem length of fenugreek plants compared with the untreated plants during two growing seasons. It also appear that, plants which were treated with 0.75 $\mathrm{ml} / \mathrm{L}$ showed the longest stem among the else treatments, increasing length of the main stem by 74.3 and $52.1 \%$ compared to control plants in 2015 / 2016 and 2016 / 2017 seasons, respectively.

\section{Plant height}

It is noticed from Table 2 that, the foliar usage with micronutrients at $0.25 \mathrm{ml} / \mathrm{L}$ showed no statistical impact on plant height of fenugreek plants compared with the control plants in both studied seasons, but the else used concentrations $(0.50,0.75$, and $1.00 \mathrm{ml} / \mathrm{L}$ ) treatments increased significantly plant height. The maximum value in plant height was achieved at $0.75 \mathrm{ml} / \mathrm{L}$ micronutrients, improving plant height by 69.6 and $46.7 \%$ more than the control in two seasons; respectively.

\section{Leaves number / plant}

Data in Table 2 show that, leaves number in fenugreek plant were significant inducement as a result of spraying plants with all concentrations of micronutrients in both seasons compared with the control plants. $0.75 \mathrm{ml} / \mathrm{L}$ treatment registered the highest value during two growing seasons, being 76.3 and $69.4 \%$ more than leaves number developed per control plant in 2015 / 2016 and 2016 / 2017 seasons; respectively.

\section{Number of primary branches/ plant}

Data in Table 2 indicate that, all concentrations of micronutrients used except low concentration $(0.25 \mathrm{ml} / \mathrm{L})$ gave an increment in branches number / plant compared with the untreated plants during two seasons. Plants were sprayed with $0.75 \mathrm{ml} / \mathrm{L}$ had the best number compared with the other treatments, increasing number of branches / plant by 47.2 and $57.5 \%$ more than the control in two seasons; respectively.

\section{Fresh weight of shoot / plant}

Data in Table 2 reveal that, fresh weight of shoot in fenugreek plants were increased significantly as a result of micronutrients application in both studied seasons compared with the control plants. $0.75 \mathrm{ml} / \mathrm{L}$ treatment registered the best weight during two growing seasons, being 52.3 and $63 \%$ higher than fresh weight of shoot / untreated plants in 2015 / 2016 and 2016 / 2017 seasons; respectively.

Dry weight of shoot / plant

Results in Table 2 clearly show that, all concentrations used exhibited the same trend with fresh weight. Fenugreek plants treated with all concentrations of micronutrients showed significant increments in dry weight in both studied seasons. $0.75 \mathrm{ml} / \mathrm{L}$ treatment was the most effective when compared with the other treatments, being 47.6 and $59.4 \%$ over dry weight of shoot untreated plant in 2015/2016 and 2016/2017 seasons; respectively

These results are compatible with Nour (2004) who found that application of boron at $25 \mathrm{ppm}$ and iron at $100 \mathrm{ppm}$ enhanced vegetative growth characters, dry weight of plant, yield components and seed quality of pea plants. Also, spraying broad bean plants with $\mathrm{Fe}$ at $100 \mathrm{~g}$ per fad. increased stem length, number of branches / plant, leaves number and pod setting percentage ( Mohamed \& Helal, 1999). In this concern, treatment with $B$ at 25 and $50 \mathrm{ppm}$ and $\mathrm{Fe}$ at 50 and $100 \mathrm{ppm}$ increased plant height , number of leaves and branches / plant and dry weight in pea plants, while the highest values were recorded from sprayed pea plants with $\mathrm{Fe}$ at 
100 ppm (Mansour et al., 2012) In this respect, application of a mixture of microelements (B, $\mathrm{Zn}$ and $\mathrm{Se}$ ) at 3 and $6 \mathrm{ppm}$ improved plant height, leaf area index of mungbean plant, the most effective concentration of microelements was 6 ppm (Amirani \& Kasraei, 2015) . Corn plants treated with iron at $3 \mathrm{mg} / \mathrm{L}$, zinc at $4 \mathrm{mg} /$ $\mathrm{L}$, copper at $5 \mathrm{mg} / \mathrm{L}$, manganese at $2.5 \mathrm{mg} / \mathrm{L}$, boron at $1.5 \mathrm{mg} / \mathrm{L}$ and combination among these treatments, increased plant height, leaf area index and dry weight (Safyan et al., 2012). Trehan \& Sharma (2000) showed that, zinc increased dry matter of corn, wheat and sunflower. Likewise, the promotive effect of iron may be due to iron plays essential role in plant metabolism, electron carries and enzyme activation and low solubility of inorganic iron at physiological $\mathrm{pH}$ and it is high reactivity in presence of oxygen, which brings to generation of toxic hydroxyl radicals (Hell \& Strphan, 2003). Iron is one of the most important elements in biological redox-system, enzyme activation and oxygen transferring in nitrogen fixation (Bienfait \& Van dar Mark, 1993). The vital role of boron may be due to boron is necessary element for various plant development processes, especially in vascular plants ( Reguera et al ., 2010 ). Kumar et al. ( 2009 ) found that $\mathrm{Cu}$ enhanced plant height (23\%) in wheat plant. $\mathrm{Cu}$ is vital in constructive component of several enzymes and some proteins, these proteins have key many functions in plant like respiration, photosynthesis, phenol metabolism lignin making, protein synthesis and auxin regulating (Shorrock \& Alloway, 1988).

\section{Yield and its components:}

Data presented in Table 3 demonstrated the impact of micronutrients on yield characters of fenugreek plants cv. Giza 3 throughout two growing seasons of 2015 / 2016 and 2016 / 2017.

TABLE 3. Impact of micronutrients at different concentrations on yield characters of fenugreek plants.

\begin{tabular}{|c|c|c|c|c|c|c|c|c|}
\hline \multirow{3}{*}{ Treatments } & \multicolumn{6}{|c|}{ Yield characters } & \multirow{2}{*}{\multicolumn{2}{|c|}{ Weight of 100 seeds }} \\
\hline & \multicolumn{2}{|c|}{$\begin{array}{c}\text { No. of pods/ } \\
\text { plant }\end{array}$} & \multicolumn{2}{|c|}{ No. of seeds/plant } & \multicolumn{2}{|c|}{ Yield of seeds / plant (g) } & & \\
\hline & $\begin{array}{c}1^{\text {st }} \\
\text { season }\end{array}$ & $\begin{array}{c}2^{\text {nd }} \\
\text { season }\end{array}$ & $\begin{array}{c}1^{\text {st }} \\
\text { season }\end{array}$ & $\begin{array}{c}2^{\text {nd }} \\
\text { season }\end{array}$ & $\begin{array}{c}1^{\text {st }} \\
\text { season }\end{array}$ & $\begin{array}{c}2^{\text {nd }} \\
\text { season }\end{array}$ & $\begin{array}{c}1^{\text {st }} \\
\text { season }\end{array}$ & $\begin{array}{c}2^{\text {nd }} \\
\text { season }\end{array}$ \\
\hline Control & 7.3 & 8.6 & 54.02 & 71.30 & 1.24 & 1.64 & 2.29 & 2.30 \\
\hline $0.25 \mathrm{ml} / \mathrm{L}$ & 8.6 & 9.3 & 69.66 & 85.56 & 1.74 & 2.05 & 2.49 & 2.39 \\
\hline $0.50 \mathrm{ml} / \mathrm{L}$ & 9.6 & 10.9 & 89.20 & 111.10 & 2.40 & 2.99 & 2.69 & 2.70 \\
\hline $0.75 \mathrm{ml} / \mathrm{L}$ & 11.3 & 12.2 & 128.80 & 147.60 & 3.73 & 4.38 & 2.90 & 2.96 \\
\hline $1.00 \mathrm{ml} / \mathrm{L}$ & 10.6 & 11.3 & 108.10 & 128.80 & 3.02 & 3.47 & 2.80 & 2.70 \\
\hline L.S.D 0.05 & 1.61 & 1.83 & 12.5 & 14.2 & 0.35 & 0.41 & 0.32 & 0.38 \\
\hline
\end{tabular}

\section{Pods number per plant}

Data in Table 3 mentioned that, during studied seasons sprayed plants with $0.50 \mathrm{ml} / \mathrm{L}, 0.75 \mathrm{ml} /$ $\mathrm{L}$ and $1.00 \mathrm{ml} / \mathrm{L}$ micronutrients induced significant rise in number of pods / plant of fenugreek compared with the control plants. On the other hand, $0.25 \mathrm{ml}$ micronutrients /L. had no significant effect on pods number / plant . The most pods number /plant was recorded at $0.75 \mathrm{ml} / \mathrm{L}$., being 54.7 and $41.8 \%$ more than the untreated plants in 2015/2016 and 2016/2017 seasons; respectively.

\section{Number of seeds per plant}

Data in Table 3 show that, number of seeds/ plant of fenugreek were increased significantly as a result of treated plants with all concentrations of micronutrients in both seasons compared with the control plants. Plants were treated with 0.75 $\mathrm{ml} / \mathrm{L}$ gave the greatest number, being 138.4 and $107 \%$ more than those of untreated plants in
2015/2016 and 2016/2017 seasons; respectively.

\section{Yield of seeds per plant}

Regarding the effect of micronutrients on yield of seeds / plant, it can be seen from Table 3 that, the effect of foliar usage with micronutrients on yield of seeds / plant of fenugreek cv. Giza 3 showed the same impact on number of seeds/ plant. Foliar application with micronutrients at concentration of $0.25,0.50,0.75$, and $1.00 \mathrm{ml} / \mathrm{L}$. significantly rise in yield of seeds per plant, plants were treated with $0.75 \mathrm{ml} / \mathrm{L}$ gave the best value, being 200 and $167 \%$ more than yield of seeds of untreated plants in 2015/2016 and 2016/2017 seasons; respectively.

\section{Weight of 100 seeds}

It is realized from Table 3 that the impact of spray application with micronutrients on weight of 100 seeds of fenugreek plant showed the same 
impact on pods number/plant . Foliar spray with micronutrients at concentration of $0.50,0.75$ and $1.00 \mathrm{ml} / \mathrm{L}$. significantly rise weight of 100 seeds. The first concentration of micronutrients $(0.25$ $\mathrm{ml} / \mathrm{L}$ ) had no significant effect on weight of 100 seeds of fenugreek plant in both seasons. The most effective treatment of micronutrients was $0.75 \mathrm{ml} / \mathrm{L}$., being 26.6 and $28.7 \%$ more than weight of 100 seeds of the control in 2015/2016 and 2016/2017 seasons; respectively.

The obtained results are agreeable with Mansour et al. (2012). They showed that, spraying pea plants with boron at $50 \mathrm{pm}$ and iron at $100 \mathrm{ppm}$ increased pods number / plant , green pod yield/ plant and total green pod yield faddan. In this respect, application a mixture of microelements (B, Zn and Se ) at 3 and 6 ppm increased thousand seed weight of mungbean plant, the most effective concentration of microelements was $6 \mathrm{ppm}$ (Amirani \& Kasraei, 2015). Corn plants treated with iron at $3 \mathrm{mg} / \mathrm{L}$, zinc at $4 \mathrm{mg} / \mathrm{L}$, copper at $5 \mathrm{mg} / \mathrm{L}$, manganese at $2.5 \mathrm{mg} / \mathrm{L}$, boron at 1.5 $\mathrm{mg} / \mathrm{L}$ and combination among these treatments, increased grain yield, grain weight and grain protein content ( Safyan et al., 2012).

\section{Some chemical constituents of seed}

The effect of micronutrients on nitrogen, protein, oil percentage and total phenolic compounds in seeds of fenugreek plants during the second season are presented in Table 4 .

\section{Nitrogen percentage}

Data in Table 4 noticeable that, general increase in nitrogen percentage was registered in seeds of fenugreek plants treated with all concentration of micronutrients except low concentration $(0.25 \mathrm{ml} / \mathrm{L})$. Also, $0.75 \mathrm{ml} / \mathrm{L}$ treatment was the greatest percentage when compared with the other treatment, being $(24.8 \%)$ than the seeds of untreated plants.

TABLE 4 . Impactof micronutrients at different concentrations on certain seed constituents of fenugreek plants in second season .

\begin{tabular}{lcccc}
\hline Treatments & Nitrogen percentage & $\begin{array}{c}\text { Crude protein } \\
\text { percentage }\end{array}$ & $\begin{array}{c}\text { Oil } \\
\text { percentage }\end{array}$ & $\begin{array}{c}\text { Phenolic compound(mg } \\
\text { gallic acid / g extract) }\end{array}$ \\
\hline Control & 3.86 & 24.12 & 4.16 & 13.96 \\
$0.25 \mathrm{ml} / \mathrm{L}$ & 4.10 & 25.62 & 5.15 & 15.38 \\
$0.50 \mathrm{ml} / \mathrm{L}$ & 4.53 & 28.31 & 5.23 & 18.63 \\
$0.75 \mathrm{ml} / \mathrm{L}$ & 4.82 & 30.12 & 7.43 & 24.66 \\
$1.00 \mathrm{ml} / \mathrm{L}$ & 4.65 & 29.06 & 5.27 & 15.43 \\
L.S.D 0.05 & 0.65 & 2.21 & 1.03 & 1.39 \\
\hline
\end{tabular}

Crude protein percentage:

Data in Table 4 indicate that, $0.50,0.75$ and $1.00 \mathrm{ml} / \mathrm{L}$. treatments significantly increased crude protein percentage in seeds of fenugreek, where $0.25 \mathrm{ml} / \mathrm{L}$. showed no significant differences. It also appears that, the most effective concentration of micronutrients was $0.75 \mathrm{ml} / \mathrm{L}$, being $(24.8 \%)$ more than the seeds of untreated plants.

\section{Oil percentage}

It is clear from Table 4 that the impact of foliar application with micronutrients on the percentage of oil in seeds of fenugreek plants showed the same effect of micronutrients on nitrogen and crude protein percentage. $0.75 \mathrm{ml} /$ $\mathrm{L}$ treatment was the most effective in increasing oil percentage, being $78.6 \%$ over the seeds of untreated plants.
Total phenolic compounds

Data in Table 4 reveal that, fenugreek plants were treated with any of the tested concentration of micronutrients showed significant increase in phenolic compound of seeds $.0 .75 \mathrm{ml} / \mathrm{L}$ treatment was the most effective on phenolic compound, being $(76.6 \%)$ over the seeds of untreated plants.

Similar results were reported by Amirani \& Kasraei (2015). They, found that mungbean plants treated with a mixture of microelements $(\mathrm{B}, \mathrm{Zn}$ and $\mathrm{Se}$ ) at 3 and $6 \mathrm{ppm}$ increment seed protein percentage. Total content of grain carbohydrates, starch, indol acetic acid, chlorophyll and protein increased in corn by using zinc and iron (Rajae \& Ziaeian, 2009). In this respect, the foliar application of microelements increased fresh and dry matter, leaf area and essential oil yield in the first and second cutting in Mentha piperita (Heidari et al., 2008) In this concern, Cakmak et 
al . (2010) reported that, iron deficiency reduced total content of protein due to direct effect of iron on protein synthesis.

\section{Anatomical structure}

Anatomy of the main stem

It is noted in Table 5 and Fig. 1 that foliar application with micronutrients at $0.75 \mathrm{ml} / \mathrm{L}$ increased the main stem diameter by $29.8 \%$ over the control. The increase in stem diameter due to the distinguished increase in all tissues except that of epidermis thickness, fibrous tissue and pith diameter which showed decrease of 2.2, 27.6 and $22.5 \%$ compared to the control. The thickness of cortex, vascular cylinder, number of vascular bundles and hollow pith diameter were increased by $7.2,65.3,7.5$ and $50.3 \%$ more than the control, respectively. It is obvious that, the increase in thickness of vascular cylinder could be attributed mainly to the increment in thickness of phloem tissue, xylem tissue, vessels number per vascular bundle and vessel diameter by 64.9 , $61,24.5$ and $5.1 \%$ over the control ; respectively.

TABLE 5. Impact of micronutrients at $0.75 \mathrm{ml} / \mathrm{L}$ on histological characters of main stem at its median portion offenugreek plants.

\begin{tabular}{|c|c|c|c|}
\hline \multirow{2}{*}{ Histological characters } & \multicolumn{3}{|c|}{ Treatments } \\
\hline & (control) & $0.75 \mathrm{ml} / \mathrm{L}$ & $\pm \%$ to control \\
\hline Stem diameter & 1671.4 & 2170.6 & +29.8 \\
\hline Thickness of epidermis & 18.8 & 18.4 & -2.2 \\
\hline Thickness of cortex & 85.8 & 92 & +7.2 \\
\hline Thickness of fibrous tissue & 55.2 & 40 & -27.6 \\
\hline Thickness of vascular cylinder & 177.7 & 293.8 & +65.3 \\
\hline Thickness of phloem tissue & 36.8 & 60.7 & +64.9 \\
\hline Thickness of xylem tissue & 110.4 & 177.8 & +61 \\
\hline Number of vascular bundles & 13.3 & 14.3 & +7.5 \\
\hline Number of vessels & 5.3 & 6.6 & +24.5 \\
\hline Vessel diameter / vascular bundles & 19.6 & 20.6 & +5.1 \\
\hline Pith diameter & 155.2 & 120.2 & -22.5 \\
\hline Hollow pith diameter & 691.2 & 1039.1 & +50.3 \\
\hline
\end{tabular}

Anatomy of the leaf

It is realized from Table 6 and Fig. 2 that foliar spraying with microelements at $0.75 \mathrm{ml} /$ $\mathrm{L}$ increment thickness of both lamina of leaflet blades and midvein of fenugreek plants cv. Giza 3 by 11.5 and $11.3 \%$ over the control; respectively. It is obvious that, the increase in thickness of lamina coulde be attributed to the prominent increase in thickness of palisade and spongy tissues by 18.1 and $17.7 \%$ more than the control; respectively. The main vascular bundle of the midvein increased in size, the increase was mainly due to the increase in length by $41.6 \%$ and in width by $35.7 \%$ compared to the control. The xylem vessels number/midvein bundle increased by $10 \%$ more than the control. Also, vessel diameter was increased by $20.4 \%$ more than the control. On the other hand, spraying with microelements at $0.75 \mathrm{ml} / \mathrm{L}$ decreased thickness of upper and lower epidermis by 14.2 and $21.5 \%$ less than the control. 


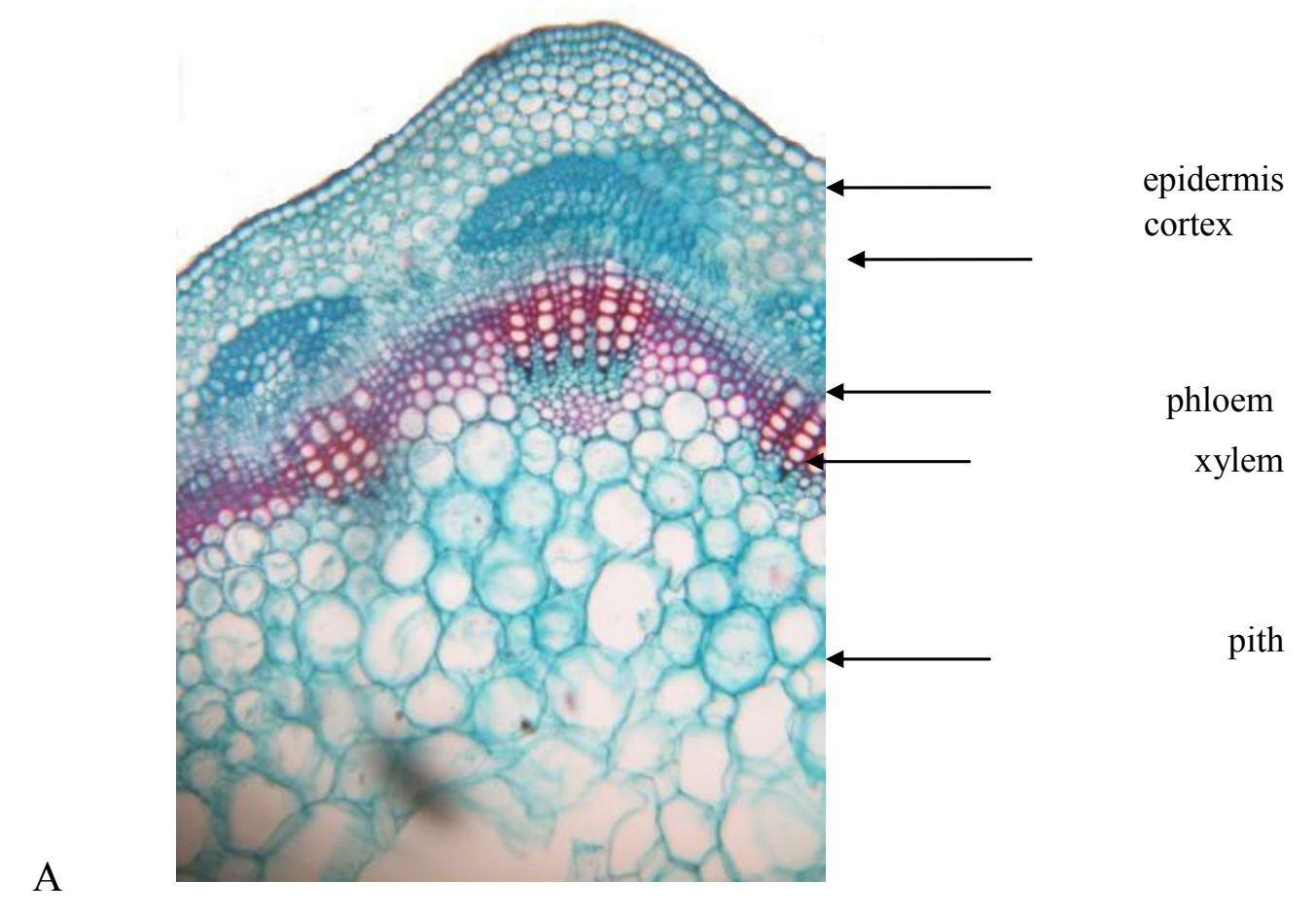

B

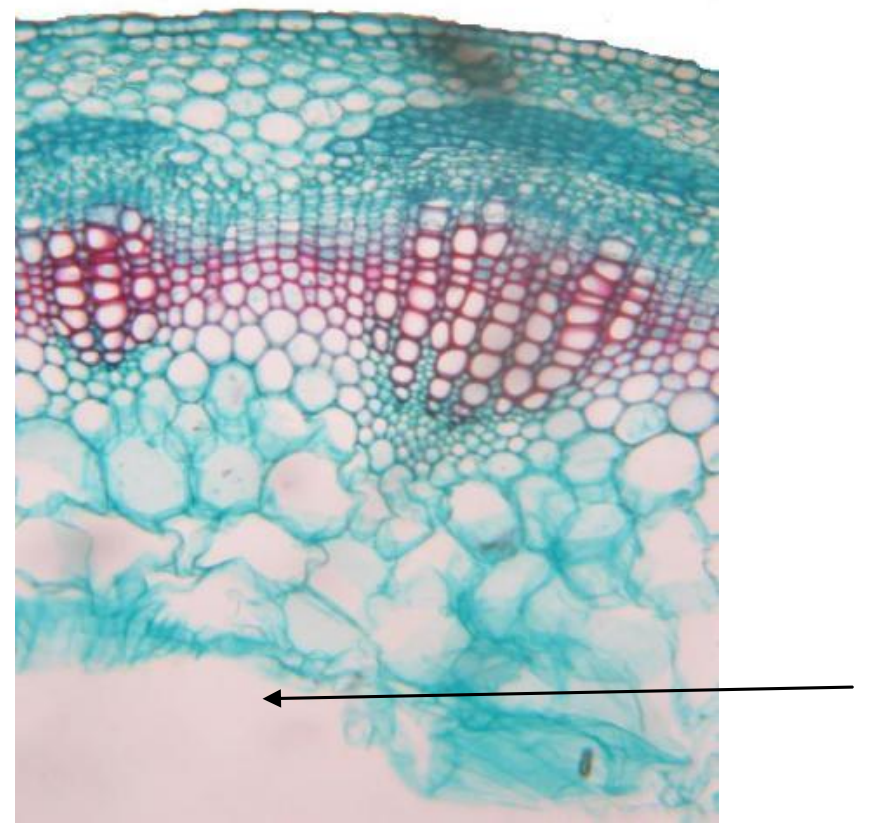

hollow pith diameter

Fig.1. Transverse sections through the fifth internode of the main stem of fenugreek plants at the age of 80 days, affected by micronutrients. $x \mathbf{4 0}$
A- From untreated plant .
B- From plant treated with $0.75 \mathrm{ml} / \mathrm{L}$. 
TABLE 6. Impact of micronutrients at $0.75 \mathrm{ml} / \mathrm{L}$ on histological characters in the blades of the upper most leaflets of the fifth compound leaf developed on the main stem of fenugreek plants.

\begin{tabular}{lccc}
\hline \multirow{2}{*}{ Histological characters } & \multicolumn{3}{c}{ Treatments } \\
\cline { 2 - 4 } & (control) & $\mathbf{0 . 7 5 ~} \mathbf{~ m l} \mathbf{~}$ & \pm \% to control \\
\hline Thickness of midvein & 496.5 & 552.7 & +11.3 \\
Thickness of lamina & 259.7 & 289.7 & +11.5 \\
Thickness of palisade tissue & 109.9 & 129.8 & +18.1 \\
Thickness of spongy tissue & 103.2 & 121.5 & +17.7 \\
Dimensions of the main vascular & & & \\
bundle of midiven & & & +41.6 \\
Length & 79.9 & 113.2 & +35.7 \\
Width & 93.2 & 126.5 & +10 \\
Number of vessels/midvein bundle & 6 & 6.6 & +20.4 \\
Vessels diameter & 16.6 & 20 & -14.2 \\
Thickness of upper epidermis & 23.3 & 20 & -21.5 \\
Thickness of lower epidermis & 23.3 & 18.3 & \\
\hline
\end{tabular}

(A)

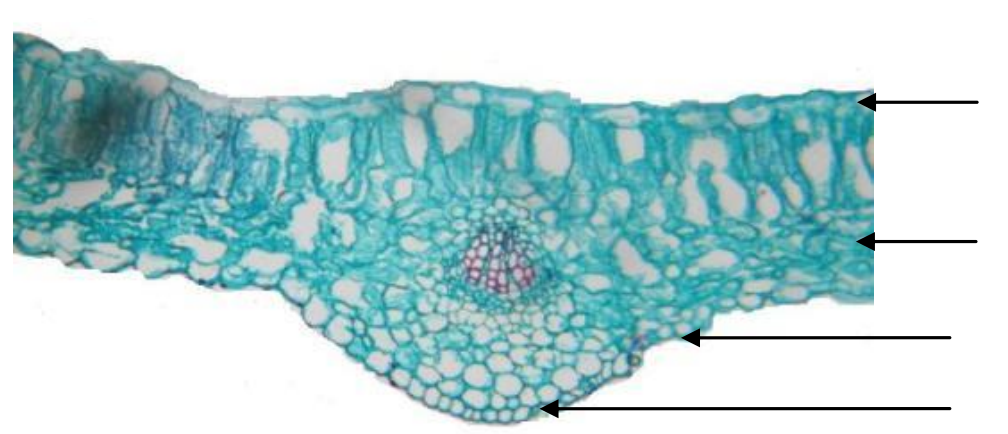

upper epidermis

spongy tissue

lower epidermis

midrib region

(B)

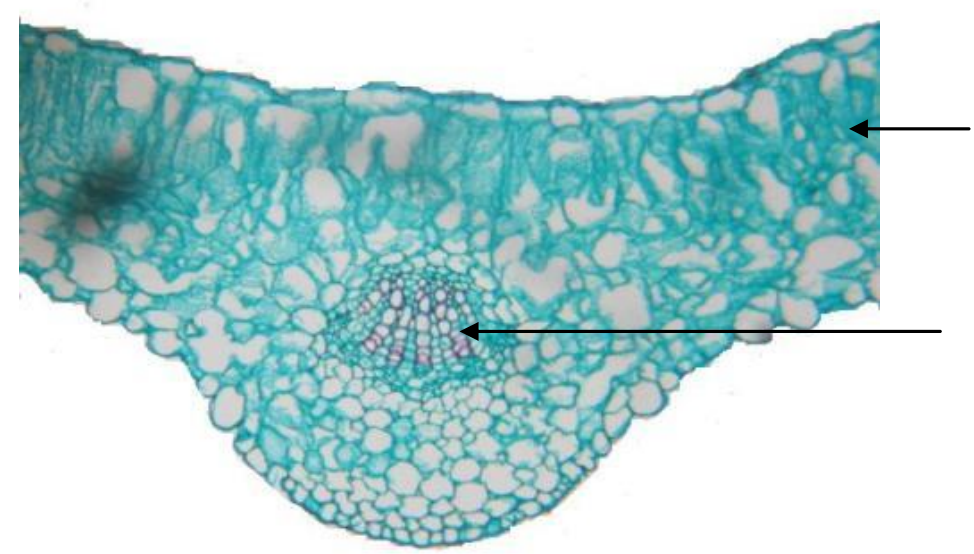

palisade tissue

midvein bundle

Fig. 2. Transverse sections through the terminal leaflet blade of the fifth compound leaf developed on the main stem of fenugreek plants at the age of 80 days, as affected by micronutrients. $x 100$
A- From untreated plant .
B- From plant treated with $0.75 \mathrm{ml} / \mathrm{L}$. 


\section{References}

A.O.A.C. (1980) Association of Official Agriculture of Chemists "Official Methods of Analysis"13 $3^{\text {th }}$ ed. Published by the A.O.A. C., P.O. Box. 540, Washington, D.C. U.S.A.

A.O.A.C. (1990) "Official Methods of Analysis". 15 ed., Association of Official Agricultural Chemists, Washington, D.C., U.S.A.

Amirani, D.C. and Kasraei, P. (2015) The effect of foliar application of microelements on phonological and physiological characteristics of mungbean under drought stress. Int. J. Agron Agric. Res. 7 (3), 1-8.

Bremner, J.M. and Mulvaney, C.S. (1982) Total nitrogen In:"Methods of Soil Anlysis", Page, A.L., R.H. Miller, and D.R. Keeney (Ed.). pp.595624,Part 2. Amer. Soc. Agron. Mdiason, W.I.USA: .

Bienfait, H.F. and Van der Mark, F. (1993) "Phtoferritin and its Role in Iron Metabolism". Academic Press, New York, pp.111-123.

Cakmak, I., Wolfgang, H. , Feiffer, P. and Mcclafferty, B. (2010) "Biofortification of Durum Wheat with Zinc and Iron". Published by AACC international Inc . 87 (1), 10-20.

Duke, A.J. (1986) "Handbook of World Economic Importance", Plemus Press, New York and London, pp. 345 .

Haehnel, W. (1984) Photosynthetic electron transport in higher plants. Аnnu . Rev. Plant Physiol. 35, 659.

Heidari, F., Zehtab, S.S., Javanshir, A., Aliari, H. and Dadpoor, M.R. (2008) Effects of microelemints application and plant density on yield and morphological characters peppermint . Agric. Res. 8 ( 1 ), 119-131.

Hell, R. and Strphan, U. (2003) Iron Uptake, trafficking and homeostasis in plants, Planta, 216, 541-551.

Kumar, R., Mehrotra, N.K. Nautiyed, B.D, Kumar, P. and Singh, P.K. (2009) Effect of copper on growth, yield and concentration of $\mathrm{Fe}, \mathrm{Mn}, \mathrm{Zn}$ and $\mathrm{Cu}$ in wheat plants. J. Environ. Bio. 30 (4), 485-488.

Loomis, R.S. and Conner, D.J. (1992) "Crop Ecology: Productivity and Management in Agricultural Systems". Cambridge University Press, Cambridge.

Mansour, T.S., Mostafa, Doaa M. and EL-Hakim, W.M. (2012) Effect of potassium dissolving bacteria and foliar application with some microelements on growth, yield and quality of pea plant under sandy soil coditions. Zgazizg J. Agric. Res. 39 (50), 837848 .
Marchner, H. (1995) "Mineral Nutrition of Higher Plant", $2^{\text {nd }}$ ed. Academic Press, London.

Mohamed, F.I. and Helal, F.A. (1999) Effect of planting method and foliar spray with manganese, zinc, boron and iron on growth, green yield and its components and chemical content of broad bean plants, Minufiya J. Agric. Res. 24 (30), 1033-1045.

Nassar, M.A. and El-Sahhar, K.F. (1998) "Botanical Preparations and Microscopy (Microtechnique)". Academic Bookshop, Dokki, Giza, Egypt, pp.219 (In Arabic).

Nour, E.M.E. (2004) Physiological studies on pea crop under sandy soil condition. Ph.D. Tesis, Fac. Agric., Zagazig Univ., Egypt.

Petit, P.R., Sauvaire, Y.D. Hillaire, D.M. Leconte, O.M., Baissac, Y.G., Ponsin, G.R. and Rao, C.V. (1995) Steroid saponin from fenugreek seeds: extraction, purification and pharmacological investigation on feeding behavior and plasma cholesterol. Steroids, 60 (10), 674-80.

Rajaie, M. and Ziaeian, A.H. (2009) Combined effect zinc and boron on yield and nutrients accumulation in corn. Inter. J. Plant Production, 3 (3), 35-44.

Reguera, M.,Wimmer, M., Bbustos, P., Goldbach, H.E., Bolanos, L. and Bonilla, I. (2010) Ligands of boron in Pisum sativum nodules are involved in regulation of oxygen concentration and rhizobial infection . Plants Cell Environ. 33, 1039-1048.

Safyan, Nassrin M.R., Naderidarbaghshahi and Bahari, B. (2012) The effect of micoelements spraying on growth, qualitative and quantitative grain corn in Iran. Inter. Res. J. App. and Bacic. 3 (5), 2780-2784.

Shelp, B.J. (1993) "Physiology and Biochemistry of Boron in Plants". Ed., CRC. Press Boca, Ratan, Fl., pp.53-85.

Shorrock, V.M. and Alloway, B.J.(1988) Copper in plant, Animal and Human nutrition. International Copper Research Association, p.99 .

Škerget, M., Kotnik, P., Hadolin, M., Rižner-Hraš, A., Simonič, M. and Knez, Ž. (2005) Phenols, proanthocyanidins, flavones and flavonols in some plant materials and their antioxidant activities. Food Chem. 89, 191-198.

Snedecor, G.W. and Cochran, W.G. (1982) "Statistical Methods". The Iowa State Univ., Press, $7^{\text {th }}$ ed $2^{\text {nd }}$. Printing, p.507.

Srinivassan, K., (2006) Fenugreek ( Trigonella foenim graecum L.,): A Review of Health Beneficial Physiological Effects . Food Rev. Int. 22, 203-224. 
Trehan, S.P. and Sharma, R.C. (2000) Phosphorus and zinc uptake efficiency of Solanum tuberosum L. in comparison to Triticum aestivum L., Zea mays and Helianthus annus.Letr. J. Plant Production, 30 (4), 485-488.
Verma, V. (2007) "Textbook of Plant Physiology". Published by Ane Book Pvt.Ltd. New Delhi, India, pp. 205-234.

(Received 8/7/2017;

accepted 5/9/2017)

\title{
دور المغذيات الصغرى في تحسين المحصول وجودة البذور في نباتات الحلبة
}

\author{
قسم النبات الزر اعىـ_ كلية الزر اعة - جامعة الزقازيق - الزقازيق ـ مصر.
}

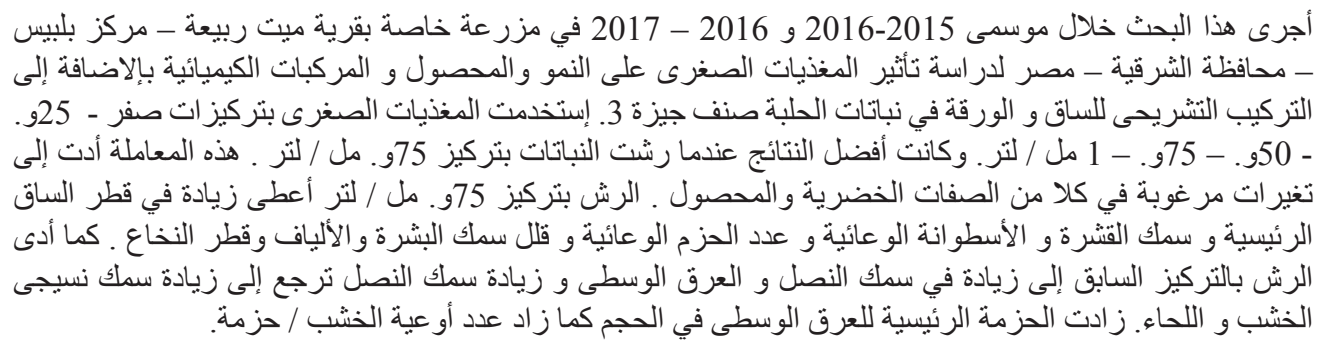

